\title{
Monoclonal Antibody Lym-2
}

National Cancer Institute

\section{Source}

National Cancer Institute. Monoclonal Antibody Lym-2. NCI Thesaurus. Code C29225.

A recombinant murine monoclonal antibody directed ag ainst a human class II molecule variant found on the surfaces of normal and neoplastic human B cells. Monoclonal antibody LYM-2 may induce cell-mediated lysis of neoplastic human B cells. (NCI04) 